\title{
MICROENCAPSULATION OF FUCOXANTHIN BY WATER-IN-OIL-IN- WATER (W/O/W) DOUBLE EMULSION SOLVENT EVAPORATION METHOD: A REVIEW
}

\section{Mikroenkapsulasi Fukosantin dengan Metode Penguapan Pelarut Emulsi Ganda Air-dalam-Minyak-dalam-Air(A/WIA): Suatu ulasan}

\author{
Dedi Noviendri* \\ ${ }^{1}$ Research and Development Center for Marine and Fisheries Product Processing and Biotechnology, \\ JI. K.S Tubun Petamburan VI, Central Jakarta, Indonesia, 10260 \\ *Correspondence Author: dedinov@yahoo.com \\ Article history: \\ Received: 21 October 2014; Revised: 13 November 2014; Accepted: 23 November 2014
}

\begin{abstract}
Fucoxanthin is a major xanthophyll present in brown seaweeds such as Sargassum binderi, S. duplicatum, Turbinaria turbinata, Padina australis, Undaria pinnatifida and Hijkia fusiformis. This carotenoid has a unique structure including oxygenic functional group such as, two hydroxy, keto, epoxy (5,6-monoepoxide), and an allenic bond. Fucoxanthin has some anticancer activities such as inhibitory property on colon cancer cells and human hepatic carcinoma HepG2 cell line. This xanthophyll also induces apoptosis of human leukemia cancer HL-60 cells, human prostate cancer PC-3 cell, human lung cancer H1299 cell line etc. Unfortunately, the poor solubility of this carotenoid in water hinders it to be a drug candidate. Fucoxanthin is also a pigment that is sensitive to temperature and light. One of the possible ways to circumvent the problem with light and temperature is by microencapsulating it. Microencapsulation (ME) in biodegradable polymers, e.g. poly(D,L-lactic-co-glycolic acid) (PLGA) is a promising approach to protect any potential drug from rapid degradation. Solvent evaporation method is the most popular technique of preparing PLGA microsphere (MS) and this technique has been extensively studied in recent years for the preparation of MS. In the water-in-oil-in-water (w/o/w) double emulsion solvent evaporation method, stability of the primary emulsion (PE) is a critical factor. When the PE is unstable, encapsulation efficiency (EE) is low. Stability of PE can be enhanced by including emulsifying agent or stabilizers such as polyvinyl alcohol (PVA). The presence of a stabilizer/ emulsifier plays a significant role in influencing particle size (PS), external morphology of microsphere and colloidal stability.
\end{abstract}

Keywords: microencapsulation, fucoxanthin, double emulsion, PLGA, microsphere

\section{ABSTRAK}

Fukosantin adalah santofil utama yang terdapat dalam rumput laut coklat seperti Sargassum binderi, S. duplicatum, Turbinaria turbinata, Padina australis, Undaria pinnatifida dan Hijkia fusiformis. Karotenoid ini memiliki suatu struktur kimia yang unik mencakup gugus fungsional oksigenik seperti dua hidroksi, keto, epoksi (5,6-monoepoksida), dan ikatan alenik. Fukosantin memiliki beberapa aktivitas antikanker seperti, sifat penghambatan pada sel kanker kolon dan sel lestari HepG2 karsinoma hepatik manusia. Santofil ini juga menginduksi apoptosis pada sel HL-60 kanker leukemia, sel PC-3 kanker prostat, sel lestari H1299 kanker paru-paru manusia dan lain-lain. Sayangnya, kelarutan karotenoid ini dalam air adalah rendah sehingga menghambat untuk menjadikannya sebagai kandidat obat. Fukosantin juga merupakan pigmen yang sensitif terhadap suhu dan cahaya. Satu cara yang mungkin untuk mengatasi masalah dengan cahaya dan suhu ini adalah dengan mengenkapsulasinya. Mikroenkspsulasi (ME) dalam polimer biodegradabel, misalnya poly(D,L-lactic-co-glycolic acid) (PLGA) adalah suatu pendekatan yang menjanjikan untuk melindungi beberapa obat potensial dari degradasi yang cepat. Metode penguapan pelarut adalah teknik yang sangat populer untuk pembuatan mikrosfir PLGA dan teknik ini telah dipelajari secara intensif dalam tahun-tahun sekarang ini untuk penyiapan mikrosfir. Dalam metode penguapan emulsi ganda $w / O / W$, stabilitas emulsi primer adalah suatu faktor penentu. Ketika emulsi primer tidak stabil, maka efisiensi enkapsulasinya jadi rendah. Stabilitas emulsi primer dapat ditingkatkan dengan memasukkan zat pengemulsi atau stabilisator seperti polivinil alkohol (PVA). Keberadaan suatu penstabil dan pengemulsi adalah berperan sigifikan dalam mempengaruhi ukuran partikel, morfologi eksternal mikrosfir dan stabilitas koloidal.

Kata Kunci: mikroenkapsulasi, fukosantin, emulsi ganda, PLGA, mikrosfir

Permalink/DOI: http://10.15578/squalen.v9i3.114 


\section{Introduction}

Fucoxanthin (3'-acetoxy-5,6-epoxy-3,5'-dihydroxy6', 7'-didehydro- $5,6,7,8,5$ ', 6'-hexahydro- $\beta, \beta$-caroten-8on) is a major xanthophyll present in brown seaweed (Beppu et al., 2012; Koji \& Hosokawa, 2013). This compound contributes more than $10 \%$ of the estimated total production of carotenoids in nature (Matsuno, 2001; Miyashita, 2008), especially in the marine ecosystem (Dembitsky \& Maoka, 2007; Moghadamtousi et al., 2014). It has a unique structure including oxygenic functional group, such as two hydroxy, keto, epoxy (5,6-monoepoxide), and an allenic bond in the molecule (Maeda et al., 2008; Miyashita, 2008; Riccioni et al., 2011; Kumar et al., 2013; Miyashita, 2014). Its structure differs from that of common carotenoids (Ishikawa et al., 2008) such as $\beta$-carotene and lycopene (Tsukui et al., 2007). The chemical structures of fucoxanthin and other epoxy xanthophylls are shown in Figure 1. The sources of fucoxanthin from brown seaweeds are summarized in Table 1.

\section{Fucoxanthin and its Anticancer Activity}

Fucoxanthin, a major carotenoid in brown seaweed (Das et al., 2008) exhibits inhibitory property on colon cancer cells, and this effect was associated with growth arrest (Das et al., 2008), inhibited the growth of human hepatic carcinoma HepG2 cell line (Das et al., 2008), and enhanced the antiproliferative effect of the peroxisome proliferator-activated receptor (PPAR) gamma ligand troglitazone on colon cancer cells (Hosokawa, 2004). Furthermore, fucoxanthin also induced apoptosis of human leukemia HL-60 cells
(Kotake-Nara et al., 2005b), human prostate cancer PC-3 cell line (Kotake-Nara et al., 2005a), and human lung cancer H1299 cell line (Jaswir et al., 2011a Noviendri, 2014; Noviendri et al., 2014a) (Figure 2 and 3).

The activity of fucoxanthin as anticancer agent is shown in Table 2. In addition, fucoxanthin and its two metabolites, fucoxanthinol and halocynthiaxanthin have antioxidant activities. The proposed metabolic transformation of fucoxanthin to fucoxanthinol then finally converted to amarouciaxanthin $A$ is shown in Figure 4. This metabolic conversion was observed in mice and in human hepatoma cell HepG2 (Asai et al., 2004; Hashimoto et al., 2009).

\section{Definition and the Main Reasons for Microen- capsulation (ME)}

ME has been defined as the technology of packaging or coating of solid, gaseous and liquid materials with a thin protective layer or wall material (McNamee et al., 1998) or in small capsules that release their contents at controlled rates over prolonged periods of time (Campagne \& Fustier, 2007). ME is a well-known technique that is used to delay and modify drug release from pharmaceutical dosage forms (Kim et al., 2002). ME in biodegradable polymers, e.g. poly-(D,L-lactic-co-glycolic acid) (PLGA), was found to be a promising approach to protect the potential compounds from rapid degradation (Wischke \& Borchert, 2006). Moreover, a large number of ME techniques are available for the formation of sustained release (Wischke \& Borchert, 2006) microparticulate drug delivery systems (Kim et al., 2002). Furthermore, microparticles (MPs) or

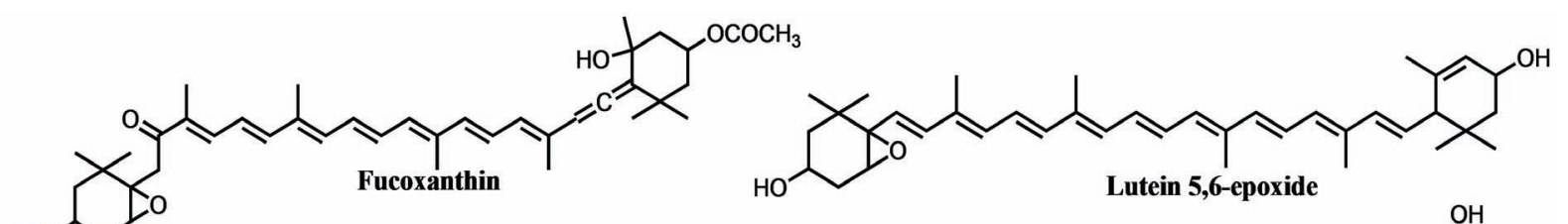

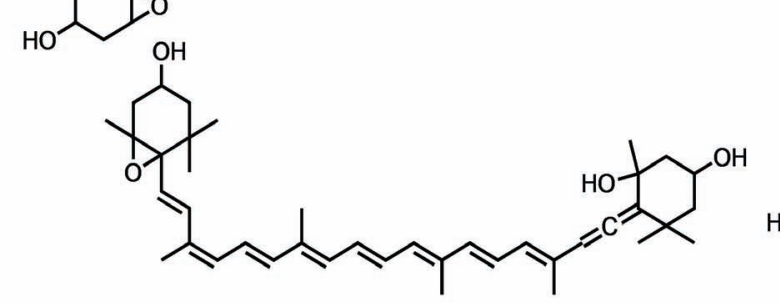

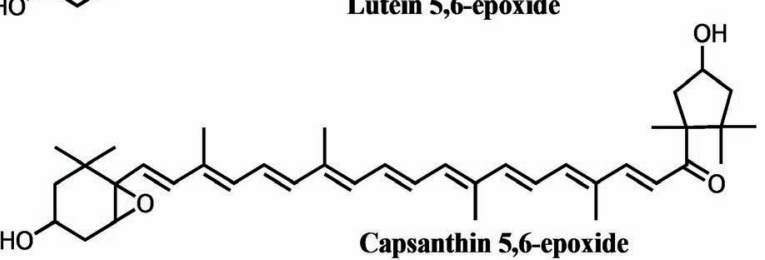

9'-cis-Neoxanthin

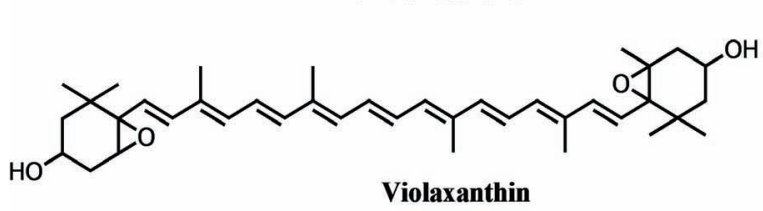

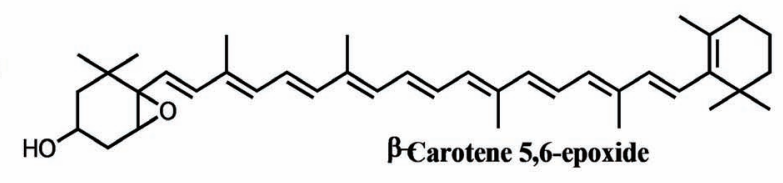

Figure 1. Chemical structures of various epoxy xanthophylls (Redrawn from Kotake-Nara and Nagao, 2011). 
Table 1. Fucoxanthin in brown seaweeds

\begin{tabular}{|c|c|}
\hline $\begin{array}{l}\text { Species of brown } \\
\text { seaweeds }\end{array}$ & References \\
\hline Alaria crassifolia & Terasaki et al., 2009; Airanthi et al., 2011a. \\
\hline Analipus japonicus & Terasaki et al., 2009. \\
\hline Cladoshipon ok amuranus & Mise et al., 2011; Tafuku et al., 2012. \\
\hline Cystoseira hakodatensis & Terasaki et al., 2009; Airanthi et al., 2011a. \\
\hline C. barbata & Ryabushko et al., 2014. \\
\hline Eisenia bicyclis & Airanthi et al., 2011a. \\
\hline Fucus distichus & Terasaki et al., 2009. \\
\hline F. evanescences & Tatiana et al., 2013 \\
\hline F. vesiculosus & Zaragozá et al., 2008. \\
\hline Hijk ia fusiform is & Maeda et al., 2007; Maeda et al., 2006; Urikura et al., 2011. \\
\hline Himanthalia elongate & Rajauria and Abu-Ghannam, 2013. \\
\hline Hincksia mitchellae & Wu et al., 2014 \\
\hline Hormophysa triquetra & Nursid et al., 2013. \\
\hline Ishige ok amurae & Kim et al., 2010. \\
\hline Kjellmanielly crassifolia & Airanthi et al., $2011 \mathrm{a}$. \\
\hline Laminaria japonica & Das et al., 2008; Zhang et al., 2008; Miyata et al., 2009. \\
\hline L. ochtotensis & Miyata et al., 2009. \\
\hline Laminaria $\mathrm{sp}$ & Das et al., 2005; Das et al., 2008. \\
\hline Leathesia diiformis & Terasaki et al., 2009. \\
\hline Melanosiphon intestinalis & Terasaki et al., 2009. \\
\hline Myagiopsis myagroide & Heo et al., 2010. \\
\hline Padina australis & $\begin{array}{l}\text { Zailani \& Purnomo, 2011; Jaswir et al., 2011a; Nursid et al., 2013; } \\
\text { Noviendri, } 2014 .\end{array}$ \\
\hline P. tetrastromatica & Sangeetha et al., 2009; Sangeetha et al., 2010. \\
\hline Saccharina sculpera & Terasaki et al., 2009. \\
\hline Sargassum confusum & Terasaki et al., 2009. \\
\hline S. binderi & $\begin{array}{l}\text { Noviendri et al., 2010; Noviendri et al., 2011a and 2011b; Jaswir et al., } \\
\text { 2011b; Jaswir et al.,2012; Nursid et al., 2013; Noviendri, 2014; Yip et al., } \\
\text { 2014. }\end{array}$ \\
\hline S. duplicatum & $\begin{array}{l}\text { Noviendri et al., 2010; Noviendri et al., } 2011 \text { a and 2011b; Jaswir et al., } \\
2011 \text { b; Jaswir et al., 2012; Noviendri, } 2014 .\end{array}$ \\
\hline S. echinocarpu & Zailani \& Purnomo, 2011. \\
\hline S. horneri & Terasaki et al., 2009; Airanthi et al., 2011a. \\
\hline S. ilicifolium & Nursid et al., 2013 \\
\hline S. filipendula & Zailani \& Purnomo, 2011; Zailanie \& Sukosa, 2014. \\
\hline S. fulvellum & Maeda et al., 2007; Terasaki et al., 2009; Urikura et al., 2011; \\
\hline S. fusiforme & Terasaki et al., 2009 \\
\hline S. plagyophillum & $\begin{array}{l}\text { Jaswir et al., 2011b; Noviendri et al., 2011b; Jaswir et al., 2013; Noviendri, } \\
2014\end{array}$ \\
\hline S. siliquastrum & Soo-Jin et al., 2008; Soo-Jin \& You-Jin, 2009; Heo et al., 2010. \\
\hline S. thunbergii & Terasaki et al., 2009. \\
\hline Silvetia babingtonii & Terasaki et al., 2009. \\
\hline Turbinaria conoides & Zailani \& Purnomo, 2011. \\
\hline T. decurens & Nursid et al., 2013. \\
\hline T. turbinata & $\begin{array}{l}\text { Jaswir et al., 2011b; Noviendri et al., 2011b; Jaswir et al., 2013; Noviendri, } \\
2014 .\end{array}$ \\
\hline Undaria pinnatifida & $\begin{array}{l}\text { Hosokawa, 2004; Maeda et al., 2006; Maeda et al., 2009; Sachindra et al, } \\
\text { 2007; Nakazawa et al., 2009; Airanthi et al., 2011b; Liu et al., 2011; Urikura } \\
\text { et al., 2011. Fung, 2012; Fung et al., 2013; Kanda et al., 2014; Wang et } \\
\text { al., 2014. }\end{array}$ \\
\hline
\end{tabular}



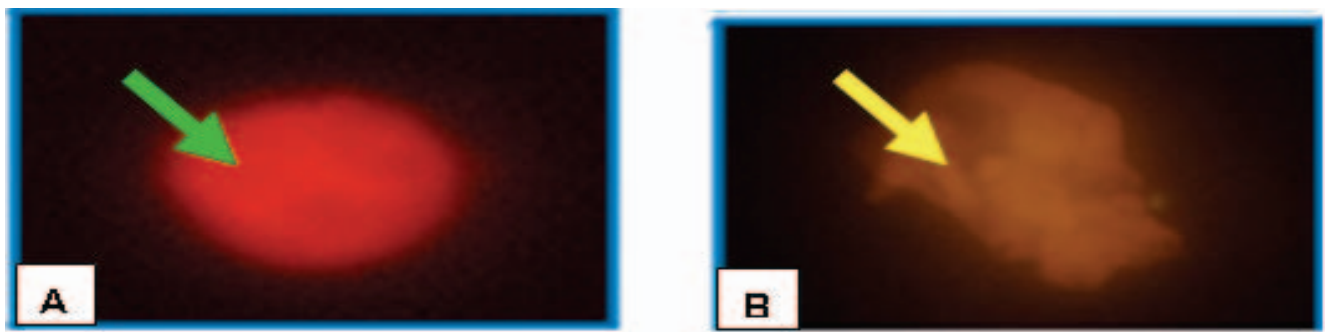

Figure 2. Fluorescence microscopy images of nuclei morphology of H1299 cells. Nuclear morphology of control cells (untreated cell) $(A)$, cells treated with fucoxanthin $\left(\mathrm{IC}_{50}=163.40 \mu \mathrm{g} / \mathrm{ml}\right)(B)$. Live and healthy cells appearing red color (green arrow) and apoptotic cells show yellow-green (yellow arrow). The cells were viewed under an Olympus inverted fluorescent microscope and photographed as described under Materials and Methods (Noviendri, 2014; Noviendri et al., 2014a).
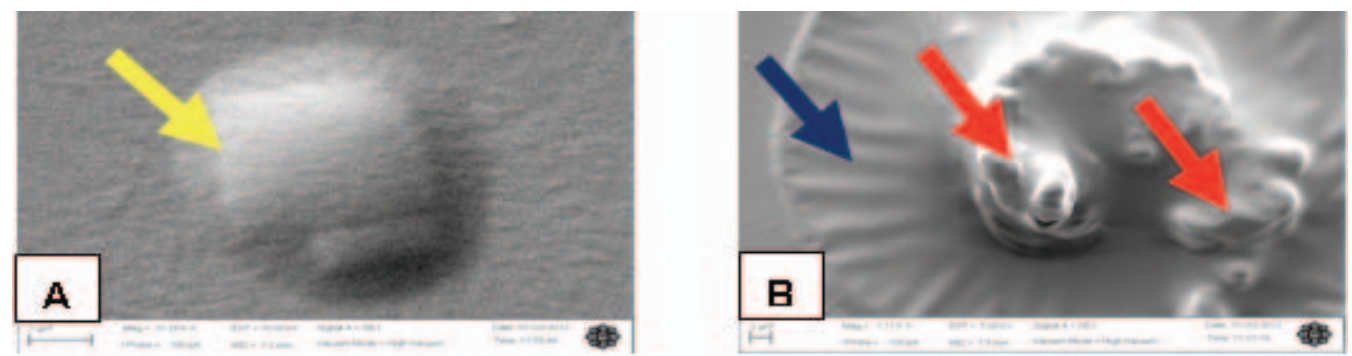

Figure 3. Scanning electron micrographs of surface ultrastructural characteristics of $\mathrm{H} 1299$ cells. Cells untreated (control cells) $(A)$, cells treated with fucoxanthin $\left(I_{50}=163.40 \mu \mathrm{g} / \mathrm{ml}\right)(B)$. Cells were viewed under a scanning electron microscope (SEM) (Carl Zeiss Evo® 50, Germany). Live and healthy cells appeared a normal membrane with smooth surface (yellow arrow), and features of apoptotic cells such as membrane blebbing (blue arrow) and formation of apoptotic bodies (red arrows) (Noviendri, 2014; Noviendri et al., 2014a).

Table 2. Fucoxanthin and its anticancer activity

\begin{tabular}{ll}
\hline Anticancer activity of fucoxanthin & \multicolumn{1}{c}{ References } \\
\hline Bladder cancer & Zhang et al., 2008. \\
Breast adenocarcinoma cancer & Wang et al., 2014. \\
Cervix squamous carcinoma cancer & Wang et al., 2014. \\
Colon carcinoma cancer & Hosokawa et al., 2004; Das et al., 2005; Eid et al., \\
& 2012; Wang et al., 2014. \\
Hepatoma cancer & Yoshiko \& Hoyoku, 2007; Das et al., 2008; Liu et \\
& al., 2009; Satomi \& Nishino, 2009; Liu et al., 2011; \\
& Wang et al., 2014. \\
Leukemia cancer & Yamamoto et al., 2011; Kotake-Nara et al., 2005b; \\
& Kim et al., 2010., Liu et al., 2013 \\
Lung cancer & Jaswir et al., 2011a; Noviendri, 2014; Noviendri et \\
& al., 2014a; Wang et al., 2014. \\
Neuroblastoma cancer & Wang et al., 2014. \\
Osteosarcoma cancer & Rokkaku et al., 2013 \\
Prostate cancer & Asai et al., 2004; Kotake-Nara et al., 2005a; \\
& Satomi \& Nishino, 2009; Satomi, 2012. \\
\hline
\end{tabular}


microspheres (MSs) have some of interesting advantages as summarized in Table 3.

\section{Techniques of ME}

ME techniques are grouped into two basic categories, namely chemical and physical techniques, with the latter being further subdivided into physicomechanical and physico-chemical techniques (Table 4) (Ghosh, 2006). Furthermore, biodegradable PLGA MSs or MPs can be prepared by several methods, but the most widely used techniques are solvent evaporation, phase separation (coacervation), and

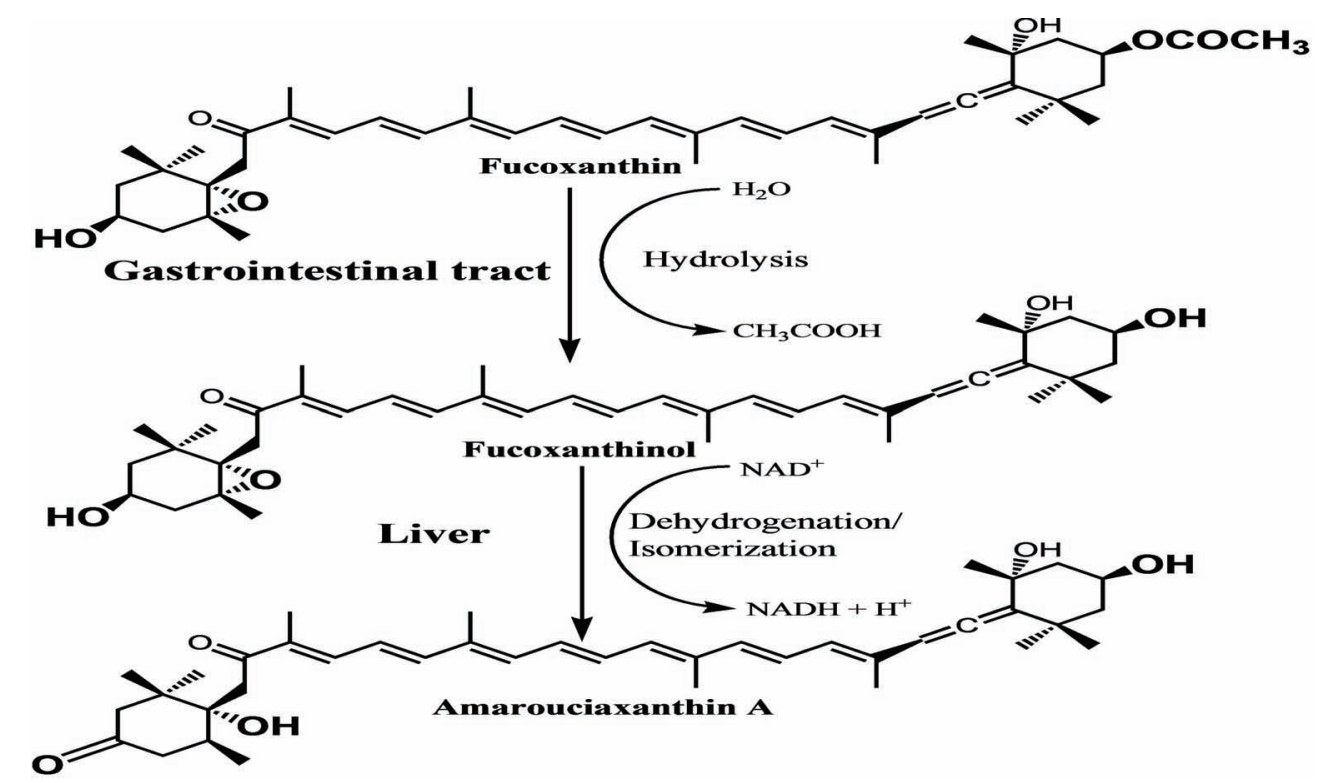

Figure 4. Proposed metabolic transformation of dietary fucoxanthin in mammals (Redrawn from: Sugawara et al., 2002; Asai et al., 2004; Maoka, 2011; Kotake-Nara \& Nagao, 2011; Niwano \& Beppu, 2012; Miyashita, 2014; Moghadamtousi et al., 2014).

Table 3. The advantages of ME technique

\section{Reason for ME technique}

To protect the sensitive compounds from the external environment factors such as moisture, oxygen, heat or light.

To mask the organoleptic properties like odor, taste and colour of the compounds.

To obtain controlled release of the substance of drug.

For sustained or prolonged drug release.

To modify and retard drug release.

For safe handling of the toxic materials.

To get targeted release of the drug.

To minimise negative effects like gastric irritation of the drug.

\section{References}

Jyothi et al., 2010; Shekhar et al., 2010; Singh et al., 2010; Ahmad et al., 2011.

Dubey et al., 2009; Yoshizawa, 2004; Jyothi et al., 2010; Shekhar et al., 2010; Ahmad et al. 2011.

Jyothi et al., 2010.

Dubey et al., 2009; Jyothi et al., 2010; Shekhar et al., 2010.

Naha et al., 2008

Carrasquillo et al., 2001; Jyothi et al., 2010.

Dubey et al., 2009; Jyothi et al., 2010.

Jyothi et al., 2010; Shekhar et al., 2010. 
Table 4. Two basic groups of ME techniques

\begin{tabular}{lll}
\hline \multirow{1}{*}{ Chemical process } & \multicolumn{2}{c}{ Physical process } \\
\cline { 2 - 3 } $\begin{array}{l}\text { Suspension, dispersion and } \\
\text { emulsion polymerization }\end{array}$ & Spray drying & $\begin{array}{l}\text { Supercritical } \mathrm{CO}_{2} \text {-assisted } \\
\text { microencapsulation }\end{array}$ \\
Polycondensation & Centrifugal technique & Layer-by-layer assembly \\
& $\begin{array}{l}\text { Multiple nozzle-sprying } \\
\text { Vacuum encapsulation }\end{array}$ & Sol-gel encapsulation \\
& Fluid-bed coating \\
\hline
\end{tabular}

Source: Ghosh (2006).

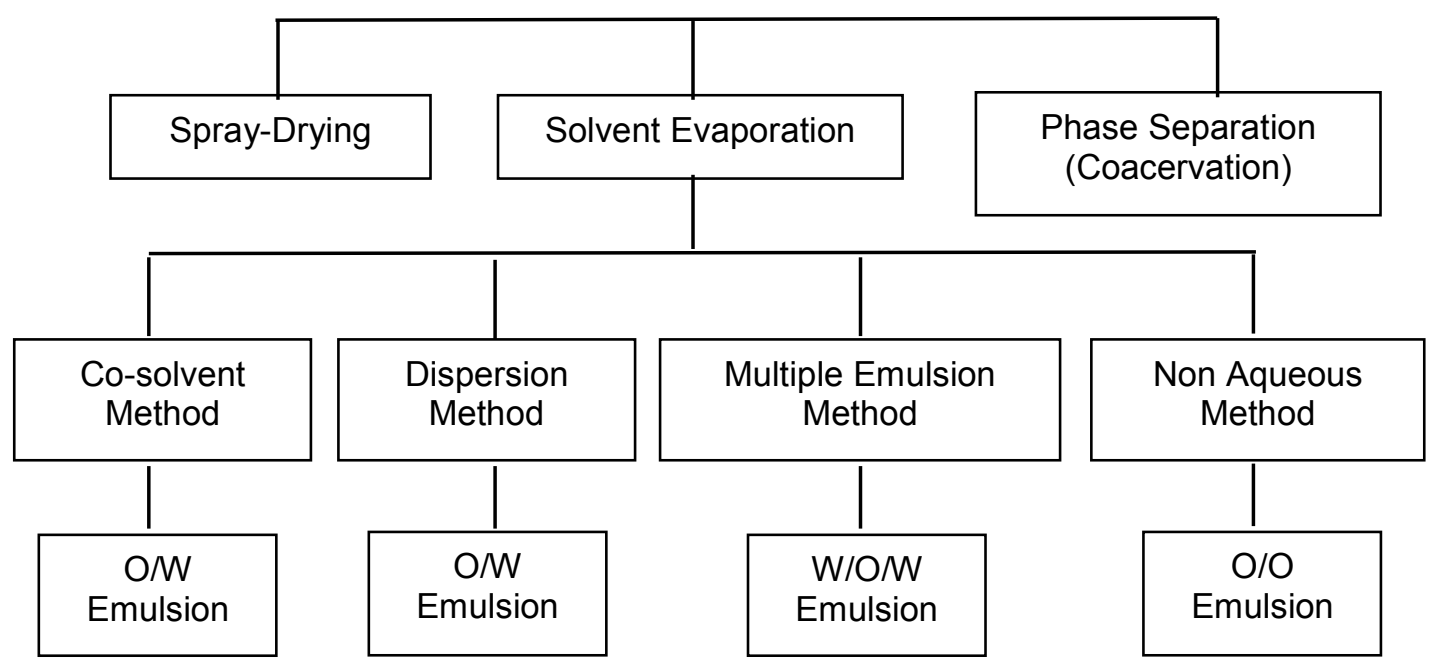

Figure 5. Several methods for preparation of PLGA MSs (Manca, 2009).

spray drying (Figure 5) (Manca, 2009). However, Mainardes and Evangelista (2005) reported the most commonly used ME technique is based on the concept of solvent and employs methylene chloride or dichloromethane (DCM) (Ansary et al., 2014) and water as disperse and continuous phase, respectively, in an emulsion type system.

\section{Water-in-oil-in-water (w/o/w) Double Emulsion Solvent Evaporation Technique}

Jaraswekin et al., (2007), and Sahoo et al., (2011) have reported that solvent evaporation method is the most popular technique of preparing PLGA MSs or MPs. This method does not require phase separation inducing agents or elevated temperatures (Freitas et al., 2005; Emami, 2009), and ME could also be easily scaled up to produce sterile microcapsules (Emami,
2009). Depending on the state of drug in the dispersion medium and the polymer solution, this method can be further classified into w/o/w double emulsion, waterin-oil (w/o) and oil-in-water (o/w) methods (Manca, 2009). Then, from several available methods, the w/o/ w double emulsion solvent evaporation is the most widely used method for preparation of MSs (Chaudari et al., 2010).

The technique of ME by emulsion solvent evaporation removal technique has been applied extensively in pharmaceutical industries to obtain the controlled release of drug (Li et al., 2008), protection of the drugs from degradation, and protection of the body from the negative effects of the drugs (Obeidat, 2009). This method has been widely used to prepare MSs loaded with various drugs, especially hydrophobic drugs (Yeo et al., 2001). Moreover, because of their 


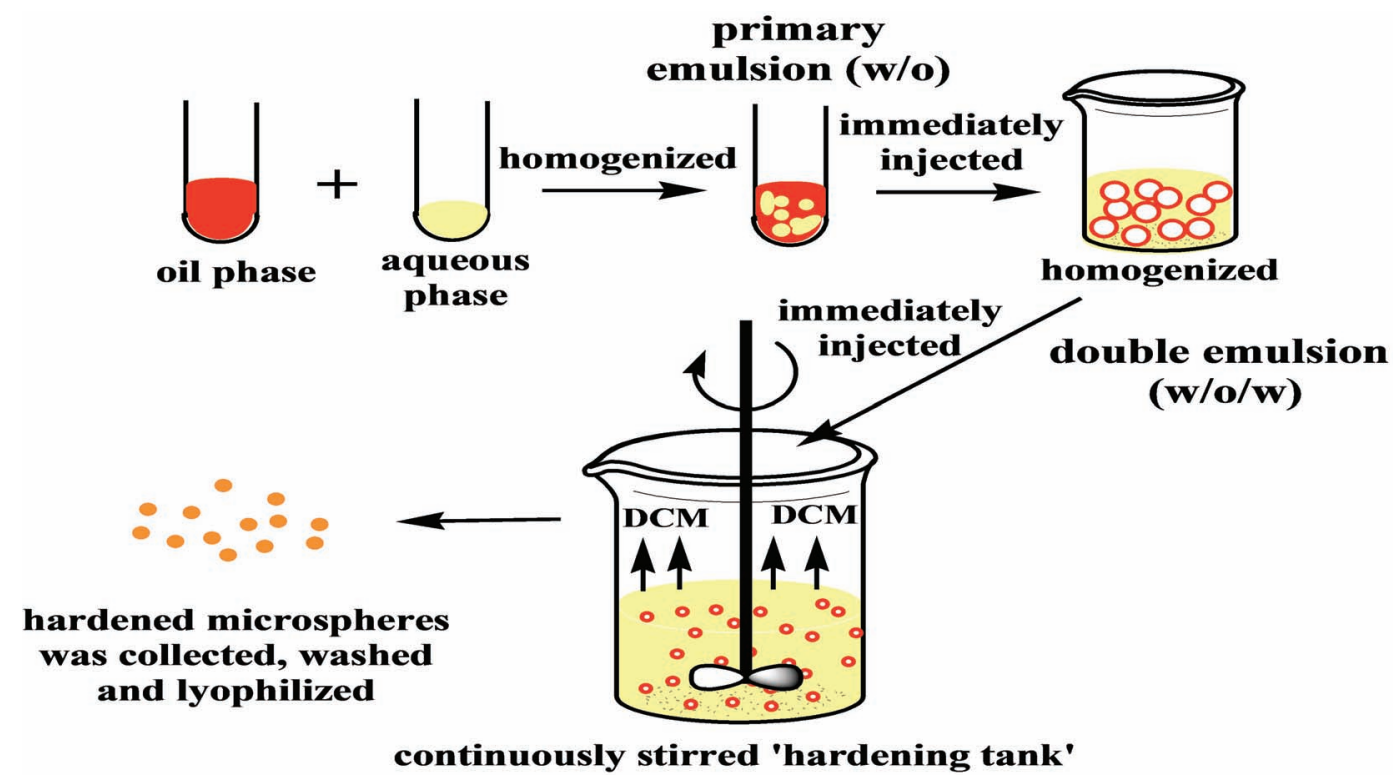

Figure 6. Schematic diagram of w/o/w double emulsion solvent evaporation method of microsphere synthesis (Redrawn from Mohamed, 2008).

encapsulation and protection efficiency, w/o/w double emulsions solvent evaporation are potentially suitable materials for applications in various domains such as cosmetics, pharmaceutics, and foods (Bonnet et al., 2010).

In the w/o/w double emulsion solvent evaporation method (Figure 6), stability of the primary emulsion $(P E)$ is a critical factor for efficient internalization of the active ingredient (Maa \& Hsu, 1997). When the $P E$ is unstable, encapsulation efficiency (EE) is low. Stability of PE can be enhanced by including emulsifying agent or stabilizers such as polyvinyl alcohol (PVA) (Yang et al., 2001), Tween-80, or Span80 (Li et al., 2008). The presence of a stabilizer/ emulsifier (Mu \& Feng, 2003) plays a significant role in influencing particle size (PS), external morphology of microsphere (Noviendri, 2014) (Figure 7), and colloidal stability (Karata et al., 2009).

\section{Biodegradable polymers for Microspheres (MSs)}

Polymers used in ME are of two types (Alagusundaram et al., 2009), namely synthetic polymers and natural polymers. The synthetic polymers are divided into two types: (a) nonbiodegradable polymers e.g. epoxy polymers, acrolein and glycidyl methacrylate, (b) biodegradable polymers e.g. lactides, glycolides and their copolymer poly anhydrides, poly-(ortho esters) and polyesters such as PLGA, and others. Natural polymers are obtained from different sources like, carbohydrate, chemically modified carbohydrate and chemically modified protein, such as hyaluronic acid, chitosan and alginic acid (Figure 8).

Among the different classes of biodegradable polymers, poly(lactide) (PLA) and PLGA are the most commonly used as drug carrier due to their biodegradability, mechanical strength (Athanasiou, 1996), biocompatibility, and versatility in terms of physical, chemical and biological properties (Mohamed, 2008). Furthermore, some of the requirements of biodegradable polymers can be summarized as follows (Llyod, 2002):

1. The substance should have suitable processibility and permeability for the intended application.

2. The degradation time of the substance should match the healing.

3. The substance should not evoke a toxic response upon implantation in the body.

4. The substance should have acceptable shelf life. The substance should have appropriate mechanical properties for the indicated application. The degradation products should be non-toxic, and able to get metabolized and cleared from the body.

\section{Poly-(D, L-lactic-co-glycolic acid) (PLGA)}

PLGA polymer is synthesized from homopolymer lactide and glycolide, respectively (Bouissou \& Walle, 2006; Ansary et al., 2014) (Figure 9). PLGA polymer is most popular among the various synthetic 

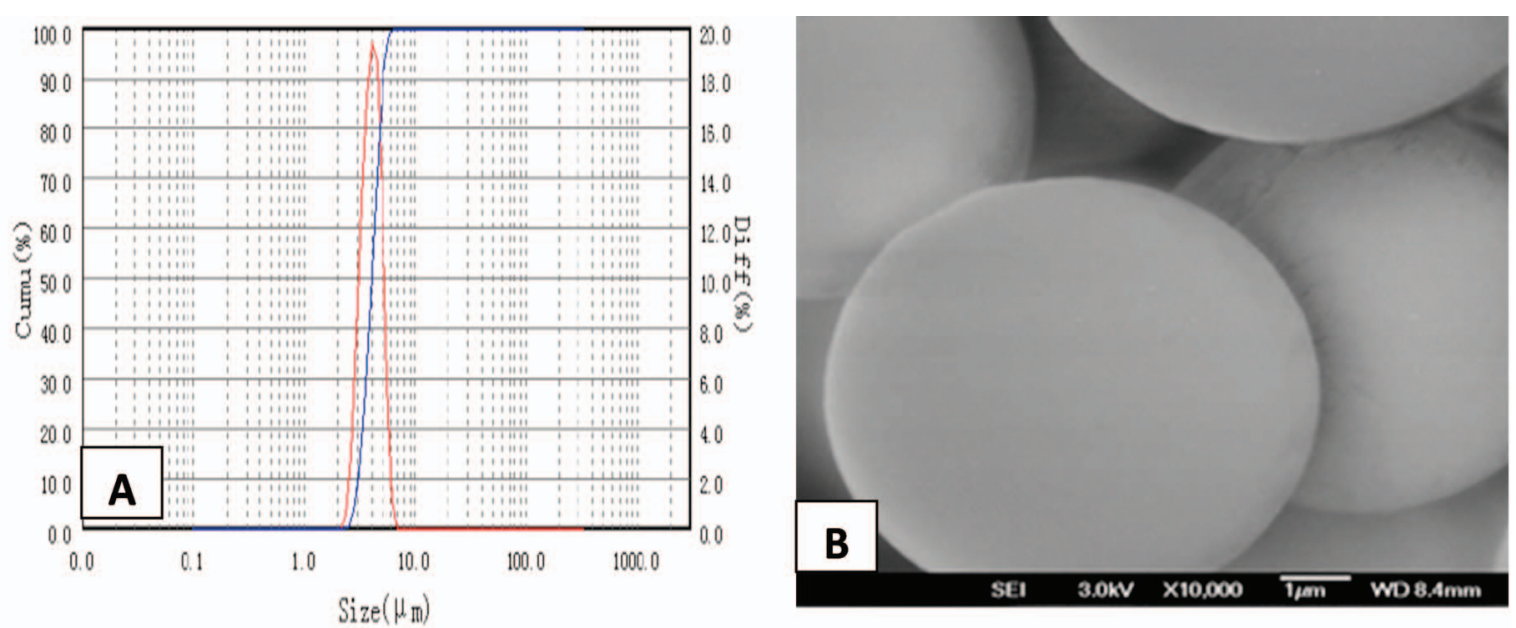

Figure 7. A representative of particle size (PS) distribution of fucoxanthin-loaded microsphere (F-LM) by using a laser particle size analyser (LPSA) (A), and a representative of morphology of F-LM by using field emission-scanning electron microscope (FE-SEM) with magnification of 10,000X (B) (Noviendri, 2014; Noviendri et al., 2014b).<smiles>CC(C)(C)OC(=O)C(C)(C)C</smiles>

Polyesters<smiles>CCOC1(OC)CCCO1</smiles>

Poly(ortho esters)<smiles>CC(C)(C)OPC(C)(C)OC(C)(C)C(=O)OC(C)(C)C</smiles>

Polyanhydrides

Natural Polymers

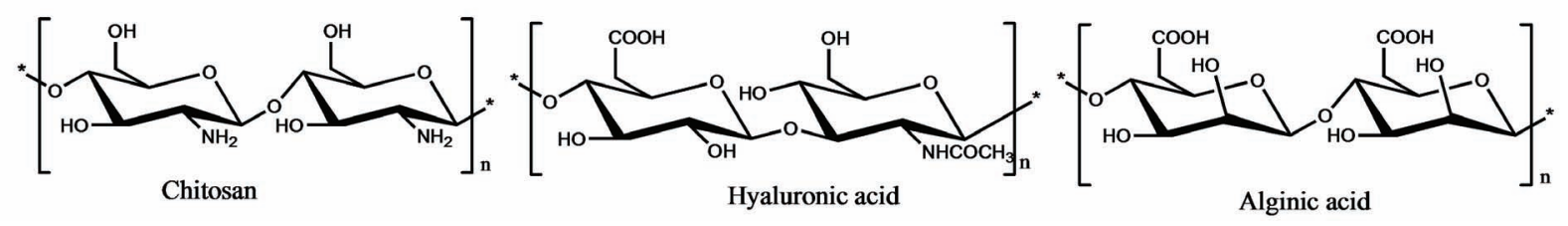

Figure 8. Chemical structures of several biodegradable polymers (Park et al., 2005).<smiles>CC(O)C(=O)O</smiles>

Lactic acid<smiles>COC(=O)C(C)OC(=O)C(C)OC(=O)O</smiles><smiles>O=C(O)CO</smiles>

Glycolic acid<smiles>CCC(O)(CC)C(=O)C(C)OC(CC)(CC)C(C)(C)CC</smiles>

Poly (D, L-lactic-co-glycolic acid) (PLGA)

Figure 9. Synthetic scheme of poly-(D, L-lactic-co-glycolic acid) (PLGA)(Ansary et al., 2014). 
biodegradable polymers (Varde \& Pack, 2004) for pharmaceutical (Çirpanli et al., 2009) and biomedical applications (Emami et al., 2009), because it has been approved by the United State Food and Drug Administration (US FDA) for clinical usage (Makadia \& Siegel, 2011; Wang, 2012), and biocompatibility (Cai et al., 2009; Çirpanli et al., 2009; Chaudhari et al., 2010).

The use of biodegradable MSs or MPs as drug delivery system offers various advantages, such as: (i) the improvement of bioavailability (Barakat \& Ahmad, 2008), (ii) no need of (surgical) removal, (iii) easy administration (Siepmann et al., 2004), (iv) the possibility to accurately control the release rate of an incorporated drug, (v) enhancement of stability and targeting a drug to specific sites (Barakat \& Ahmad, 2008), (vi) desire, pre-programmed drug release profile can be provided which matchs the therapeutic needs of the patients (Singh et al., 2010), (vii) localized drug delivery and, (viii) high local drug concentration (Berkland et al., 2003).

\section{Biodegradation of PLGA}

Among the families of synthetic polymers, PLGA have been attractive for pharmaceutical and medical applications because of their ease of degradation by hydrolysis of ester linkage (Gunatillake \& Adhikari, 2003; Makadia \& Siegel, 2011). In addition, PLGAcan be degraded into oligomeric and finally monomeric acids (Tsai, 2003; Siepmann et al., 2004; Makadia \&
Siegel, 2011) (Figure 10) including lactic acid and glycolic acid that are nontoxic to the human body (Torres-Lugo \& Peppas, 2000), and can be completely biodegraded into $\mathrm{CO}_{2}$ and $\mathrm{H}_{2} \mathrm{O}$ (Yamaguchi et al., 2002). Furthermore, in the human body, polyglycolides are broken down into glycine (amino acid) which can be excreted in the urine or converted into $\mathrm{CO}_{2}$ and $\mathrm{H}_{2} \mathrm{O}$ via the citric acid cycle (Torres-Lugo \& Peppas, 2000; Maurus \& Kaeding, 2004; Mohamed, 2008).

The rate of the PLGA biodegradation are dependent on the molecular weight (MW) of the polymer and the molar ratio of the glycolic and lactic acids in the polymer chain (Park, 1995), the degree of crystallinity (Tracy et al., 1999), and the glass transition temperature $(\mathrm{Tg})$ of the polymer (Makadia \& Siegel, 2011). The $\mathrm{Tg}$ of the MSs increase with increasing MW of PLGA. However, the MS preparation was not found to affect the $\mathrm{Tg}$ of the polymer (Tsai, 2003). The degradation rate of PLGA is inversely correlated to the crystallinity of the polymer since water does not penetrate easily into the crystalline regions (Tracy et al., 1999; Tsai, 2003). PLGA, which is amorphous, will degrade faster than either of its semi-crystalline homo-polymers (DeLuca et al., 1993).

For example, the biodegradability analysis of fucoxanthin-loaded microsphere (F-LM) was based on the change in morphology of microspheres (MSs). The change in morphology of F-LM with time following incubation in $0.1 \mathrm{M}$ phosphate buffer saline (PBS) $(\mathrm{pH}$ 7.4 ) at $37^{\circ} \mathrm{C}$ in static condition is shown in Figure 11.<smiles>CCOC(=O)COC(C)C(=O)O</smiles>

PLGA<smiles>CC(C)C(=O)OCCO</smiles>

Lactic Acid<smiles>CCCOC(=O)O</smiles>

Glycolic Acid

Figure 10. Hydrolysis of PLGA (Redrawn from Makadia and Siegel, 2011).
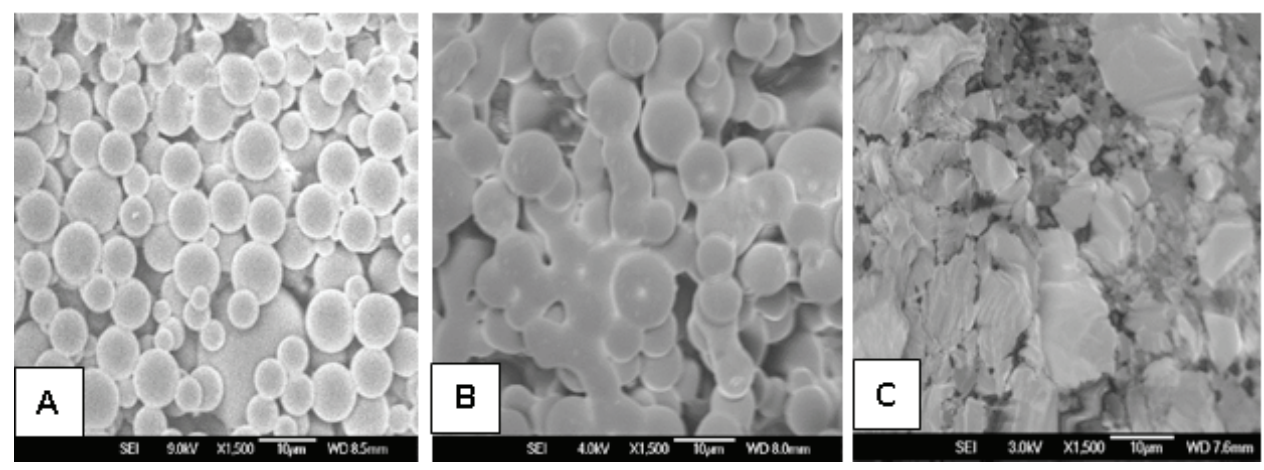

Figure 11. Morphology change of Fucoxanthin-Loaded Microsphere (F-LM): control (A), after 1 month (B) and after 2 months (C) by using FE-SEM with magnification of 1500X (Noviendri, 2014; Jaswir et al., 2014). 
Noviendri (2014) and Jaswir et al., (2014) have reported that electron micrograph of F-LM before incubation (control) showed spherical, discrete MSs with smooth surface (Figure 11A). The major changes in F-LM morphology were observed within 1 month, the F-LM had deformed, aggregated, fused and the F-LM morphologies had turned into an unstructured mass (Figure 11B). Finally, the F-LM were totally collapsed and disintegrated into irregular particles, and no intact spheres were observed (Figure 11C). The F-LM fabricated from PLGA (50/50) as coating needs 2 months for their degradation (Noviendri, 2014; Jaswir et al., 2014). Wang (2012) reported that PLGA (50/ $50)$ polymer degraded in approximately $1-2$ months, PLGA 75/25 and PLGA 85/15 are degraded $4-5$ months and 5-6 months, respectively.

\section{Conclusion}

Microencapsulation of fucoxanthin in biodegradable polymers, e.g. poly(D,L-lactic-co-glycolic acid) (PLGA) is a promising approach to protect fucoxanthin from the light, temperature, rapid degradation and to increase fucoxanthin solubility in the water. Solvent evaporation method is the most popular technique of preparing PLGA microsphere (MS) and this technique has been extensively studied in recent years for the preparation of fucoxanthin-loaded microsphere (F-LM). Because of their encapsulation and protection efficiency, w/o/w double emulsions solvent evaporation are potentially suitable materials for applications in various domains such as cosmetics, pharmaceutics, and foods. In the w/o/w double emulsion solvent evaporation method, stability of the primary emulsion $(P E)$ is a critical factor for efficient internalization of the active ingredient. The F-LM fabricated from PLGA (50/50) as coating needs 2 months for their degradation. The F-LMs were totally collapsed and disintegrated into irregular particles, and no intact spheres were observed under field emission-scanning electron microscope (FE-SEM).

\section{References}

Ahmad, M., Madni, A., Usman, M., Munir, A., Akhtar, N. \& Khan, H. M. S. (2011). Pharmaceutical Microencapsulation Technology for Development of Controlled Release Drug Delivery systems. World Acad. Sci. Eng. Technol., 75, 384-387.

Airanthi, M. W. A., Hosokawa, M. \& Miyashita, K. (2011a). Comparative antioxidant activity of edible Japanese brown seaweeds. J. Food Sci., 76, C104-C111.

Airanthi, M. K. W. A., Sasaki, N., Iwasaki, S., Baba, N., Abe, M., Hosokawa, M. \& Miyashita, K. (2011b). Effect of brown seaweed lipids on fatty acid composition and lipid hydroperoxide levels of mouse liver. J. Agric. Food Chem., 59, 4156-4163.
Alagusundaram, M., Madhu, S. C. C., Umashankari, K., Attuluri, V. B., Lavanya, C. \& Ramkanth, S. (2009). Microspheres As a Novel Drug Delivery System - A Review. Int. J. ChemTech Res., 1(3), 526-534.

Ansary, R. H., Awang, M. B. \& Rahman, M. M. (2014). Biodegradable Poly(D,L-lactic-co-glycolic acid)Based Micro/Nanoparticles for Sustained Release of Protein Drugs-A Review. Trop. J. Pharm. Res., 13(7), 1179-1190.

Asai, A., Sugawara, T., Ono, H., \& Nagao, A. (2004). Biotransformation of Fucoxanthinol into Amarouciaxanthin A in Mice and HepG2 Cells; Formation and Cytotoxicity of Fucoxanthin Metabolites. Drug Metabol. Dispos., 32(2), 205-211.

Athanasiou, K. A., Niederauer, G. G., \& Agrawal, C. M. (1996). Sterilization, toxicity, biocompatibility and clinical applications of polylactic acid/polyglycolic acid copolymers. Biomaterials, 17, 93-102.

Barakat, N. S. \& Ahmad, A. A. E. (2008). Diclofenac sodium loaded-cellulose acetate butyrate: Effect of processing variables on microparticles properties, drug release kinetics and ulcerogenic activity. J. Microencapsulation., 25, 31-45.

Beppu, F., Hosokawa, M., Niwano, Y., \& Miyshita, K. (2012). Effects of dietary fucoxanthin on cholesterol metabolism in diabetic/obese $\mathrm{KK}-A^{y}$ mice. Lip. Health Dis., 11(112), 1-8.

Berkland, C., Kim, K. \& Pack, D. W. (2003). PLG microsphere size controls drug release rate through several competing factors. Pharma. Res., 20, 10551062.

Bonnet, M., Canseli, M., Placin, F., David-Briand, E., Anton, M. \& Leal-Calderon, F. (2010). Influence of Ionic Complexation on Release Rate Profiles from Multiple Water-in-Oil-in-Water (W/O/W) Emulsions. J. Agric. Food Chem., 58, 7762-7769.

Bouissou, C. \& Walle, C. F. V. D. (2006). Poly(lacticcoglycolic acid) Microspheres. In I. F. Uchegbu \& A. G. Schatzlein (Eds.), Polymers in Drug Delivery (1st ed.) New York: CRC Press. pp. 81-94.

Brady, J. M., Cutright, D. E., Miller, R. A., Battistone, G. C. \& Hunsuck, E. E. (1973). Resorption rate, route of elimination, and ultrastructure of the implant site of polylactic acid in the abdominal wall of the rat. $J$. Biomed. Mat. Res., 7(2), 155-166.

Cai, C., Mao, S., Germershaus, O., Schaper, A., Rytting, E., Chen, D. \& Lissel, T. (2009). Influence of morphology and drug distribution on the release process of FITC-dextran-loaded microspheres prepared with different types of PLGA. J. Microencapsulation, 26(4), 334-345.

Carrasquillo, K. G., Stanley, A. M., Aponte-Carro. J. C. D. E., Jesus, P., Contantino, H. R., \& Bosques, C. J. (2001). Non-aqueous encapsulation of excipientstabilized spray-freeze dried BSA into poly(lactideco-glycolide) microspheres results in release of native protein. J. Control. Rel., 76, 199-208.

Champagne, C. P. \& Fustier, P. (2007). Microencapsulation for the improved delivery of bioactive compounds into foods. Curr. Opin. Biotechnol., 18, 184-190.

Chaudhari, K. R., Shah, N., Patel, H., \& Murthy, R. (2010). Preparation of porous PLGA Microspheres with 
thermoreversible gel to modulate drug release profile of water-soluble drug: Bleomycin sulphate. J. Microencapsulation, 27(4), 303-313.

Çirpanli, Y., Robineau, C., Çapan, Y. \& Çaliº, S. (2009). Etodolac Loaded Poly (Lactide-Co-Glycolide) Nanoparticles: Formulation and In Vitro Characterization. Hacettape Univ. J. Fac. Pharm., 29(2), 105-114.

Das, S. K., Hashimoto, T., Shimizu, K., Yoshida, T., Sakai, T., Sowa, Y., Komoto, A. \& Kanazawa, K. (2005). Fucoxanthin induces cell cycle arrest at $\mathrm{G}_{0} / \mathrm{G}_{1}$ phase in human colon carcinoma cells through upregulation of p21 WAF1/Cip1. Biochim. Biophys. Acta, 1726, 328-335.

Das, S. K., Hashimoto, T. \& Kanazawa, K. (2008). Growth inhibition of human hepatic carcinoma HepG2 cells by fucoxanthin is associated with down-regulation of cyclin D. Biochim. Biophys. Acta, 1780, 743-749.

Deluca, P. P., Mehta, R. C. Hausberger, A. G. \& Thanoo, B. C. (1993). Biodegradable polyesters for drug and polypeptide delivery. In El-Nokaly, M. A., Piattand, D. M. \& Charpentier, B. A. (Eds) Polymeric Delivery Systems: properties and Applications. American Chemical Society, Washington, D. D. 411 p.

Dembitsky, V. M. \& Maoka, T. (2007). Allenic and cumulenic lipids. Progr. Lipid Res., 46, 328-375.

Dubey, R., Shami, T. C. \& Rao., K. U. B. (2009). Microencapsulation Technology and Applications. Defence Sci. J., 59(1), 82-95.

Eid, S. Y., Ei-Readi, M. Z., \& Wink, M. (2012). Carotenoid reverse multidrug resistance in cancer cells by interfering with ABC-transporters. Phytomedicine. 19, 977-987.

Emami, J., Hamishehkar, H., Najafabadi, A. R., Gilani, K., Minaiyan, M., Mahdavi, H., \& Nokhodchi, A. (2009). A novel approach to prepare insulin-loaded poly(lactic-co-glicolic acid) microcapsules and the protein stability study. J. Pharm. Sci., 98(5), 17121731.

Freitas, S., Merkle, H .P. \& Gander, B. (2005). Microencapsulation by solvent extraction/evaporation: Reviewing the state of the art of microsphere preparation process technology. J. Control. Rel., 102, 313-332.

Fung, A. Y. C. (2012). The fucoxanthin Content and Antioxidant Properties of Undaria pinnatifida from Malborough Sound, New Zealand. A Masteral Thesis. Auckland University of Technology University. 78 p.

Fung, A., Hamid, N., \& Lu, J. (2013). Fucoxanthin content and antioxidant properties of Undaria pinnatifida. Food Chem., 136, 1055-1062.

Ghosh, S. K. (2006). Functional Coating and Microencapsulation: A General Perspective. Ch1. In Ghosh, S.K (Ed.) Function Coatings: by Polymer Microencapsulation. (Pp. 1-28). Wiley-VCH. Verlag GmbH \& Co, ISBN 3-527-31296-X. DOI: 10.1002/ 3527608478 .

Gunatillake, P. A. \& Adhikari, R. (2003). Biodegradable Synthetic Polymers for Tissue Engineering. Eur. Cells Mater., 5, 1-16.

Hashimoto, T., Ozaki, Y., Taminato, M., Das, S. K., Mizuno, M., Yoshimura, K., Maoka, T., \& Kanazawa, K. (2009).
The distribution and accumulation of fucoxanthin and its metabolites after oral administration in mice. $\mathrm{Br}$. J. Nutr. 102, 242-248.

Heo, S. J., Yoon, W. J., Kim, K. N., Ahn, G. N., Kang, S. M., Kang, D. H., Affan, A., Oh, C., Jung, W. K. \& Jeon, Y. J. (2010). Evaluation of anti-inflammatory effect of fucoxanthin isolated from brown algae in lipopolysaccharide-stimulated RAW 264.7 macrophages. Food Chem. Toxicol., 48, 2045-2051.

Hosokawa, M., Kudo, M., Maeda, H., Kohno, H., Tanaka, T. \& Miyashita, K. (2004). Fucoxanthin induces apoptosis and enhances the antiproliverative effect of the PPARã ligand, troglitazone, on colon cancer cells. Biochim. Biophys. Acta. 1675, 113-119.

Ishikawa, C., Tafuku, S., Kadekaru, T., Sawada, S., Tomita, M., Okudaira, T., Nakazato, T., Toda, T., Uchihara, J. N., Taira, N., Ohshiro, K., Yasumoto, T., Ohta, T. \& Mori, N. (2008). Antiadult T-cell leukemia effects of brown algae fucoxanthin and its deacetylated product, fucoxanthinol. Int. J. Cancer. 123, 2702-2712.

Jaraswekin, S., Prakongpan, S., \& Bodmeier, R. (2007). Effect of poly(lactide-co-glycolide) molecular weight on the release of dexamethasone sodium phosphate from microparticles. J. Microencapsulation. 24(2), 117-128.

Jaswir, I., Noviendri, D., Salleh, H. M., Taher, M., \& Miyashita, K. (2011a). Isolation of fucoxanthin and fatty acid analysis of Padina australis and cytotoxic effect of fucoxanthin on human lung cancer $(\mathrm{H} 1299)$ cell lines. Afr. J. Biotechnol. 10(81), 18855-18862.

Jaswir, I., Noviendri, D., Salleh, H.M., Taher, M., \& Miyashita, K. (2011b). Techniques of Extraction and Purification of Fucoxanthin from Brown Seaweeds. Ch.5. In Norbatcha, I.A., Salleh, H.M. \& Karim, M.I.A (Eds.). Experimental Methods In Modern Biotechnology. Pp. 50-64. First Edition, IIUM Press, IIUM, Malaysia. ISBN: 978-967-0225-86-9.

Jaswir, I., Noviendri, D., Salleh, M.T., Taher, M., and Miyashita, K. (2012). Fucoxanthin extractions of Brown seaweeds and Analysis of Their Lipid Fraction in Methanol. Food Sci. Technol. Res., 18(2), 251-258.

Jaswir, I., Noviendri, D., Salleh, H. M., Taher, M., Mohammed, F., \& Miyashita, K. (2013). Analysis of Fucoxanthin Content and Purification of All-TransFucoxanthin from Turbinaria turbinata and Sargassum plagyophyllum by $\mathrm{SiO}_{2}$ Open Column Chromatography and Reversed Phase-HPLC. J. Liq. Chrom. Rel. Technol., 36, 1340-1354.

Jaswir, I., Noviendri, D., Salleh, H. M., Noorbacha, I. A., Taher, M., Mohamed, F. \& Miyashita, K. (2014). Optimization and Formulation of Fucoxanthin-Loaded Microsphere (F-LM) Using Response Surface Methodology (RSM) and Analysis of Its Fucoxanthin Release Profile. J. Control. Rel., (Submitted).

Jyothi, N. V. N., Prasanna, P. M., Sukarkar, S. N., Prabha, K. S., Ramaiah, P. S. \& Srawan, G. Y. (2010). Microencapsulation techniques, factors influencing encapsulation efficiency. J. Microencapsulation, 27(3), 187-197.

Kanda, H., Kamo, Y., Machmudah, S., Wahyudiono, \& Goto, M. (2014). Extraction of Fucoxanthin from Raw 
Macroalgae excluding Drying and Cell Wall Disruption by Liquefied Dimethyl Ether. Mar. Drugs., 12, 23832396. DOI: $10.3390 / \mathrm{md} 12052383$.

Karata, A., Sonakin, Ö., Kiliçarslan, M., \& Baykara, T. (2009). Poly (e-caprolactone) microparticles containing Levobunolol $\mathrm{HCl}$ prepared by a multiple emulsion (W/O/W) solvent evaporation technique: Effects of some formulation parameters on microparticle characteristics. J. Microencapsulation. 26(1), 63-74.

Kim, B. K., Hwang, S. J., Park, J. B., \& Park, H. J. (2002). Preparation and characterization of drug-loaded polymethacrylate microspheres by an emulsion solvent evaporation metod. J. Microencapsulation. 19(6), 811-822.

Kim, K. N., Heo, S. J., Kang, S. M., Ahn, G., \& Jeon, Y. J. (2010). Fucoxanthin induces apoptosis in human leukemia HL-60 cells through a ROS-mediated BclxL pathway. Toxicol. in Vitro., 24(6), 1648-1654.

Koji, M., \& Hosokawa, M. (2013). Biosynthetic Pathway and Health Benefits of Fucoxanthin, an Algae-Specific Xanthophyll in Brown Seaweeds. Int. J. Mol. Sci., 14, 13763-13781. DOI: 10.3390/ijms140713763.

Kotake-Nara, E., Sugawara, T., \& Nagao, A. (2005a). Antiproliferative effect of neoxanthin and fucoxanthin on cultured cells. Fish. Sci., 71, 459-461.

Kotake-Nara, E., Asai, A. \& Nagao, A. (2005b). Neoxanthin and fucoxanthin induce apoptosis in PC-3 human prostate cancer cells. Cancer Lett., 220, 75-84.

Kotake-Nara, E. \& Nagao, A. (2011). Absorption and Metabolisms of Xanthophylls. Mar. Drugs., 9, 10241037.

Kumar, S. R., Hosokawa, M., \& Miyashita, K. (2013). Fucoxanthin: A Marine Carotenoid Exerting AntiCancer Effects by Affecting Multiple Mechanisms. Mar. Drugs., 11, 5130-5147. DOI: 10.3390/md11125130.

Li, M., Rouaud, O., \& Poncelet, D. (2008). Microencapsulation by solvent evaporation: State of the art for process engineering approaches. Int. J. Pharm., 363, 26-39.

Liu, C. L., Huang, Y. S., Hosokawa, M. \& Miyashita, K. \& Hu, M. L. (2009). Inhibition of proliferation of hepatoma cell line by fucoxanthin in relation to cell cycle arrest and enhanced gap junctional intercellular communication. Chemico-Biol. Interac., 182, 165172.

Liu, C-L., Lim, Y. P., \& Hu, M. L. (2011). Fucoxanthin Attenuation Rifampin-Induced Cytochrome P450 3A4 (CYP3A4) and Multiple Drug Resistance 1 (MDR1) Gene Expression Through Pregnane X Receptor (PXR)-Mediated Pathways in Human Hepatoma HepG2 and Colon Adenocarcinoma LS174T Cells. Mar. Drugs, 10, 242-257. DOI: 10.3390/md10010242.

Liu, C-L., Lim, Y-P. \& Hu, M-L. (2013). Fucoxanthin Enhanced Cisplatin-Induced Cytotoxity via NFêBMediated Pathway and Downregulateds DNA Repair Gene Expression in Human Hepatoma HepG2 Cells. Mar. Drugs., 11, 50-66. DOI: 10.3390/md11010050.

Lloyd, A. W. (2002). Interfacial bioengineering to enhance surface biocompatibility. Medic. Device Technol.,13, 18-21.

Maa, Y. F. \& Hsu, C. C. (1997). Effect of primary emulsions on microsphere size and protein-loading in the double emulsion process. J. Microencapsulation, 14, 225-241.

Maeda, H., Hosokawa, M., Sashima, T., Takahashi. N., Kawada, T. \& Miyashita, K. (2006). Fucoxanthin and its metabolite, fucoxanthinol, suppress adipocyte differentiation in 3T3-L1 cells. Int. J. Mol. Med., 18, 147-152.

Maeda, H., Hosokawa, M., Sashima, T., Funayama, K. \& Miyashita, K. (2007). Effect of Medium-chain Triacylglycerols on Anti-obesity Effect of Fucoxanthin. J. Oleo Sci., 56(12), 615-621.

Maeda, H., Tsukui, T., Sashima, T., Hosokawa, M. \& Miyashita, K. (2008). Seaweed carotenoid, fucoxanthin, as a multi-functional nutrient. Asia Pac. J. Clin. Nutr. 17(S1), 196-199.

Maeda, H., Hosokawa, M., Sashima, T., Funayama, K. M. \& Miyashita, K. (2009). Anti-obesity and anti-diabetic effects of fucoxanthin on diet-induced obesity conditions in a murine model. Mol. Med. Reports., 2, 897-902.

Mainardes, R. M. \& Evangelista, R.C. (2005). Praziquantel-loaded PLGA nanoparticles: preparation and characterization. J. Microencapsulation., 22(1), 13-24.

Makadia, H. K. \& Siegel, S. J. (2011). Poly Lactic-coGlycolic Acid (PLGA) as Biodegradable Controlled Drug Delivery Carrier. Polymers., 3, 1377-1397.

Manca, M. L. (2009). Chitosan and PLGA Microspheres as Drug Delivery System Against Pulmonary Micobacteria Infections. A PhD Thesis. Dept. of Farmaco Chimico Technologico. University of Cagliari. 134 p.

Maoka, T. (2011). Carotenoids in Marine Animals. Mar. Drugs. 9, 278-293.

Matsuno, T. (2001). Aquatic animal carotenoids. Fish. Sci., 67, 771-783.

Maurus, P. B. \& Kaeding, C. C. (2004) Bioabsorbable implant material review. Oper. Tech. Sports. Med., 12, 158-160.

McNamee, B. F., O'Riordan, E. D., \& O'Sullivan, M. (1998). Emulsification and Microencapsulation Properties of Gum Arabic. J. Agric. Food Chem., 46, 4551-4555.

Mise, T., Ueda, M., \& Yasumoto, T. (2011). Production of fucoxanthin-rich powder from Cladosiphon okamuranus. Adv. J. Food Sci. Technol., 3, 73-76.

Miyata, M., Koyama, T., Kamitani, T., Toda, T., \& Yazawa, K. (2009). Anti-obesity effect on rodents of the traditional Japanese food, tororokombu, shaved Laminaria. Biosci. Biotechnol. Biochem., 73, 23262328.

Miyashita, K. (2008). Fucoxanthin. Encyclopedia of Cancer. Springer-Verlag Berlin Heidelberg New York. P. 2. 10.1007/978-3-540-47648-1_2275.

Miyashita, K. (2014). Anti-obesity Theraphy by Food Component: Unique Activity of Marine Carotenoid, Fucoxanthin. Obes. Contr. Ther. Open Access., 1(1), 1-4.

Moghadamtousi, S. Z., Karimian, H., Khanabdali, R., Razavi, M., Firoozinia, M., Zandi, K., \& Kadir, H.A. (2014). Anticancer and Antitumor Potential of Fucoidan and Fucoxanthin, Two Main Metabolites Isolates from Brown Algae. Sci. World J., 1-10. 
Mohamed, H. F. (2008). Formulation and evaluation of polyester microspheres by solvent-evaporation method. A PhD Thesis. Strathclyde Institute of Pharmacy and Biomedical Science. University of Strathclyde. 349 p.

Mu, L. \& Feng, S. S. (2003). A novel controlled release formulation for the anticancer drug paclitaxel (Taxol®): PLGA nanoparticles containing vitamin E TPGS. J. Control. Rel., 86, 33-48.

Naha, P. C., Kanchan, V., Manna, P. K. \& Panda, A. K. (2008). Improved bioavailability of orally delivered insulin using Euragit-L30D coated PLGA microparticles. J. Microencapsulation. 25, 1-9.

Nakazawa, Y., Sashima, T., Hosokawa, M., \& Miyashita, K. (2009). Comparative evaluation of growth inhibitory effect of stereoisomers of fucoxanthin in human cancer cell lines. J. Funct. Food. 1, 88-97.

Niwano, Y. \& Beppu, F. (2012). In vivo and In vitro Toxicity Studies of Fucoxanthin, a Marine Carotenoid. In: Kim, $\mathrm{S}, \mathrm{K}$. (Ed.). Handbook of Marine Macroalgae: Biotechnolgy and Applied Phycology. Ch. 15. John Willey \& Sons, Ltd. Pp. 321-328.

Noviendri, D., Jaswir, I., Salleh, M., \& Miyashita, K. 2010. Extraction and Purification of Fucoxanthin from Malaysian Brown Seaweeds. Proceedings of International Annual Symposium on Sustainability Science and Management. UMTAS 2010, University Malaysia Terengganu (UMT), Malaysia. Vol. 2. pp 600605.

Noviendri, D., Jaswir, I., Salleh, H. M., Taher, M., Miyashita, K. \& Ramli, N. (2011a). Fucoxanthin extraction and fatty acid analysis of Sargassum binderi and $S$. duplicatum. J. Med. Plant Res., 5(11), 2405-2411.

Noviendri, D., Jaswir, I., Salleh, H. M., Taher, M., and Miyashita, K. (2011b). Techniques of Extraction and Purification of Carotenoid (Fucoxanthin) from Brown Seaweed. Workshop on seaweed processing for pharmaceutical applications. Organized By Bioprocess and Molecular Engineering Research Unit (BPMERU), Department of Biotechnology Engineering, Faculty of Engineering, International Islamic University Malaysia (IIUM). Kuala Lumpur, Malaysia. May $16^{\text {th }}, 2011$. (A manual book). 26p.

Noviendri, D. (2014). Isolation and Microencapsulation of Fucoxanthin for Drug Delivery System of Human Lung Cancer (H1299) Cell Line. A PhD thesis. Faculty of Engineering, International Islamic Univ. Malaysia. $225 p$.

Noviendri, D., Jaswir, I., Salleh, H. M., Noorbacha, I. A., Taher, M., Mohamed, F. \& Miyashita, K. (2014a). Apoptosis-Inducing Effect of Fucoxanthin before and after Microencapsulation on Human Lung Cancer (H1299) Cell Line. J. Biosci. Bioeng., (Submitted).

Noviendri, D., Jaswir, I., Salleh, H. M., Noorbacha, I. A., Taher, M., Mohamed, F. \& Miyashita, K. (2014b). Fabrication of Fucoxanthin-Loaded Microsphere (FLM) By Two Steps Double-Emulsion Solvent Evaporation Method and Characterization of Fucoxanthin before and after Microencapsulation. Coll. Surf. B: Biointerfaces-J., (Submitted).

Nursid, M., Wikanta, T. \& Susilowati, R. (2013). Aktivitas Antioksidan, Sitotoksisitas dan Kandungan Fukosantin Ekstrak Rumput laut Coklat dari Pantai
Benuangeun, Banten. JPB Kelautan dan Perikanan. 8(1), 73-84. (In Indonesia).

Obeidat, W.M. (2009) Recent patents review in microencapsulation of pharmaceuticals using the emulsion solvent removal methods. Recent Patents Drug Deliv. Formul., 3, 178-192.

Park, J. H., Ye, M. \& Park, K. (2005). Biodegradable Polymers for Microencapsulation of Drugs. Molecules. 10, 146-161.

Park, T. G. (1995). Degradation of poly(lactic-co-glycolic acid) microspheres: Effect of copolymer composition. Biomaterials. 16, 1123-1130.

Rajauria, G. \& Abu-Ghannam, N. (2013). Isolation and Partial Characterization of Bioactive Fucoxanthin from Himanthalia elongate Brown Seaweed: A TLC-Based Approach. Int. J. Anal. Chem., 2013, 1-6.

Riccioni, G., D'Orazio, N., Franceschelli, S. \& Speranza, L. (2011). Marine Carotenoids and Cardiovascular Risk Markers. Mar. Drugs. 9, 1166-1175.

Rokkaku, T., Kimura, R., Ishikawa, C., Yasumoto, T., Senba, M., Kanaya, F., \& Mori, N. (2013). Anticancer effects of marine carotenoids, fucoxanthin and its deacetylated product, fucoxanthinol, on osteosarcoma. Int. J. Oncol., 43, 1176-1186.

Ryabushko, V.I., Prazukin, A. V., Popova, E. V. \& Nekhoroshev, M. V. (2014). Fucoxanthin of brown alga Cystoseira barbata (Stackh.) C. Agardh from the Black Sea. J. Black Sea/Mediterranean Environ.,. 20(2), 108113.

Sachindra, N. M., Sato, E., Maeda, H., Hosokawa, M., Niwano, Y., Kohno, M. \& Miyashita, K. (2007). Radical scavenging and singlet oxygen quenching activity of marine carotenoid fucoxanthin and its metabolites. J. Agric. Food Chem. 55, 8516-8522.

Sahoo, S. K., Barik, S., Dehury, G., Dhala, S., Kanungo, S., Barik, B. B., \& Puhan, K. K. (2011). Evaluation of Controlled Release Theophylline Microspheres Prepared with Cellulose Acetate Using Solvent Evaporation Method. Trop. J. Pharm. Res., 10(2), 195201.

Satomi, Y. (2012). Fucoxanthin induces GADD45A expression and G1 arrest with SAPK/JNK activation in LNCap human prostate cancer cells. Anticancer Res., 32, 807-813.

Satomi, Y. \& Nishino, H. (2009). Implication of mitogenactivated protein kinase in the induction of $\mathrm{G} 1$ cell cycle arrest and gadd 45 expression by the carotenoid fucoxanthin in human cancer cells. Biochim.Biophys.Acta. 1790, 260-266.

Sangeetha, R. K., Bhaskar, N. \& Baskaran, V. (2009). Comparative effects of â-carotene and fucoxanthin on retinol deficiency induced oxidative stress in rats. Mol. Cell. Biochem., 331(1-2), 59-67.

Sangeetha, R. K., Bhaskar, N., Divakar, S., \& Baskaran, V. (2010). Bioavailability and metabolism of fucoxanthin in rats: structural characterization of metabolites by LC-MS (APCI). Mol. Cell. Biochem., 333, 299-310.

Shekhar, K., Madhu, M. N., Pradeep, B., \& Banji, D. (2010). A Review on Microencapsulation. Int. J. Pharm. Sci. Rev. Res., 5(2), 58-62.

Siepmann, J., Faisant, N., Akiki, J., Richard, J. \& Benoit, J. P. (2004). Effect of size of biodegradable 
microparticles on drug release: experiment and theory. J. Control. Rel., 96, 123-134.

Singh, M. N., Hemant, K. S. Y., Ram, M., \& Shivakumar, H. G. (2010). Microencapsulation: a promising technique for controlled drug delivery. Res. Pharm. Sci., 5(2), 65-77.

Soo-Jin, H., Seok-Chun, K., Sung-Ming, K., Hahk-Soo, K., Jong-Pyung, K., Soo-Hyun, K., Ki-Wan, L., Man-Gi, C., \& You-Jin, J. (2008). Cytoprotective effect of fucoxanthin isolated from brown algae Sargassum siliquastrum against $\mathrm{H}_{2} \mathrm{O}_{2}$-induced cell damage. Eur. Food Res. Technol., 22, 145-151.

Soo-Jin, H. \& You-Jin, J. (2009). Protective effect of fucoxanthin isolated from Sargassum siliquastrum on UV-B induced cell damage. J. Photochem. Photobiol. B: Biol., 95, 101-107.

Sugawara, T., Baskaran, V., Tsuzuki, W., \& Nagao, A. (2002). Brown algae fucoxanthin is hydrolyzed to fucoxanthinol during absorption by Caco-2 human intestinal cells and mice. J. Nutr., 132, 946-951.

Tafuku, S., Ishikawa, C., Yasumoto, T., \& Mori, N. (2012). Anti-neoplastic effects of fucoxanthin and its deacetylated product, fucoxanthinol, on Burkitt's and Hodgkin's lymphoma cells. Oncol. Reports., 28, 1512-1518.

Tatiana, I. I., Svetlana, P. E., Sergey, A. F., Stanislaw, D. A., \& Tatiana, N. Z. (2013). Isolation of Fucoxanthin and Highly Unsaturated Monogalactosyldiacylglycerol from Brown Alga Fucus evanescens C. Agardh and In vitro Investigation of their Antitumor Activity. Mar. Biotechnol., 15(5), 606-612.

Terasaki, M., Hirose, A., Narayan, B., Baba, Y., Kawagoe, C., Yasui, H., Saga, N., Hosokawa, M., \& Miyashita, K. (2009). Evaluation of Recoverable functional lipid components of several brown seaweeds of Japan with special reference to fucoxanthin and fucosterol contents. J. Phycol., 45(4), 974-980.

Torres-Lugo, M. \& Peppas, N. A. (2000). Transmucosal delivery systems for calcitonin: a review. Biomaterials, 21(12), 1191-1196.

Tracy, M. A., Ward, K. L,, Firouzabadian, L., Wang, Y., Dong, N., Qian, R., \& Zhang, Y. (1999). Factors Affecting the Degradation Rate of Poly(Lactide-Co-Glycolide) Microspheres in Vivo and in Vitro. Biomaterials, 20, 1057-1062.

Tsai, M. C. S. (2003). Biodegradable Paclitaxel-loaded PLGA Microspheres for Regional Treatment of Peritoneal Cancers. A PhD thesis. Graduate School of Ohio State Univ. 190 p.

Tsukui, T., Konno, K., Hosokawa, M., Maeda, H., Sashima, T., \& Miyashita, K. (2007). Fucoxanthin and Fucoxanthinol Enhance the Amount of Docosahexaenoic Acid in the Liver of KKAy Obese/ Diabetic Mice. J. Agric. Food Chem., 55, 5025-5029.

Urikura, I., Sugawara, T., \& Hirata, T. (2011). Protective Effect of Fucoxanthin against UVB-Induced Skin Photoaging in Hairless Mice. Biosci. Biotechnol. Biochem., 75(4), 757-760.

Varde, N. K. \& Pack, D. W. (2004). Microspheres for controlled release drug delivery. Expert Opin. Biol. Ther., 4, 35-51.

Wang, Y. (2012). pH-sensitive and Targeted PLGA-Based Drug Delivery to Colorectal Cancer. A PhD thesis. Deakin Univ. 192 p.
Wang, S. K., Li, Y., White, W. L., \& Lu, J. (2014). Extracts from New Zealand Undaria pinnatifida Containing Fucoxanthin as Potential Functional Biomaterials against Cancer in Vitro. J. Funct. Biomater., 5, 29-42. DOI: $10.3390 / \mathrm{jfb} 502009$.

Wischke, C. \& Borchert, H. H. (2006). Influence of the primary emulsification procedure on the characteristics of small protein-loaded PLGA microparticles for antigen delivery. $J$. Microencapsulation., 23(4), 435-448.

Wu, M. T., Chou, H. N., \& Huang, C. J. (2014). Dietary Fucoxanthin Increases Metabolic Rate and Upregulated mRNA Expressions of the PGC-1alpha Network, Mitochondrial Biogenesis and Fussion Genes in White Adipose Tissues of Mice. Mar.Drugs., 12, 964-982. DOI: 10.3390/md12020964.

Yamaguchi, Y., Takenaga, M., Kitagawa, A., Ogawa, Y., Mizushima, Y. \& Igarashi, R. (2002). Insulin-loaded biodegradable PLGA microcapsules: Initial burst release controlled by hydrophilic additive. J. Control. Rel., 81, 235-249.

Yamamoto, K., Ishikawa, C., Katano, H., Yasumoto, T., \& Mori, N. (2011). Fucoxanthin and its deacetylated product, fucoxanthinol, induce apoptosis of primary effusion lymphomas. Cancer Lett., 300, 225-234.

Yang, Y. Y., Chung, T. S., \& Ng, N. P. (2001). Morphology, drug distribution, and in vitro release profiles of biodegradable polymeric microspheres containing protein fabricated by double-emulsion solvent extraction/evaporation method. Biomaterials, 22, 231241.

Yeo, Y., Baek, N., \& Park, K. (2001). Microencapsulation Methods for Delivery of Protein Drugs. Biotechnol. Bioprocess Eng., 6, 213-230.

Yip, W. H., Joe, L. S., Mustapha, W. A. W., Maskat, M. Y., \& Said, M. (2014). Characterization and Stability of Pigment Extracted from Sargassum binderi Obtained from Semporna, Sabah. Sains Malaysiana. 43(9), 1345-1354.

Yoshiko, S. \& Hoyoku, N. (2007). Fucoxanthin, a Natural Carotenoid, Induces G1 Arrest and GADD45 Gene Expression in Human Cancer Cells. In vivo. 21, 305310.

Yoshizawa, H. (2004). Trends in Microencapsulation Research. Kona., 22, 23-31.

Zailani, K. \& Purnomo, H. (2011). Fucoxanthin Content of Five Species Brown Seaweeds from Talango District, Madura Island. J. Agric. Sci. Technol. A. 1, 1103-1105.

Zailanie, K. \& Sukoso. (2014). Study on Fucoxanthin Content and its Identification in Brown Algae from Padike Vilage Talago District, Madura Islands. J. Life Sci. Biomed., 4(1), 01-03.

Zaragozá, M. C., López, D., Sáiz, M. P., Poquet, M., Pérez, J., Puig-Parellada, P., Mármol, F., Simonetti, P., Gardana, C., Lerat, Y., Burtin, P., Inisan, C., Rousseau, I., Besnard, M., \& Mitjavila, M. T. (2008). Toxicity and antioxidant activity in vitro and in vivo of two Fucus vesiculosus extracts. J. Agric. Food Chem., 56, 77737780.

Zhang, A., Zhang, P., Hamada, M., Takahashi, S., Xing, G., Liu, J., \& Sugiura, N. (2008). Potential chemoprevention effect of dietary fucoxanthin on urinary bladder cancer EJ-1 cell line. Oncol. Reports. 20, 1099-1103. 